\title{
CERITA RAKYAT “BELU MAU, SABU MAU, DAN TI’I MAU” SEBAGAI IKATAN TIGA SUKU BANGSA DAN NILAI KEARIFAN LOKAL
}

\author{
FOLKLORE "BELU MAU, SABU MAU, AND TI'I MAU" AS A BONDTHREE ETHNIC \\ GROUPS AND LOCAL WISDOM VALUE
}

\section{Erwin Syahputra Kembaren; Salimulloh Tegar Sanubarianto}

\author{
Kantor Bahasa Provinsi Nusa Tenggara Timur \\ Jalan Jenderal Soeharto, nomor 57A, Naikoten I, Kota Kupang, Indonesia \\ erwinkembaren@gmail.com
}

\begin{abstract}
(Naskah diterima tanggal 17 Februari 2021, direvisi terakhir tanggal 1 September 2021, dan disetujui tanggal 20 Oktober 2021)

DOI: https:/ / doi.org/10.26499/wdprw.v49i2.792
\end{abstract}

\begin{abstract}
Geographically, Belu, Sabu, and Rote (Ti'i) are three regencies located on three islandsfar apart in the province of East Nusa Tenggara. The three islands, regencies, and ethnic groups share folk tales that have become legends and rarely known by society and even researched. The purpose of this research is to reveal the local wisdom values contained in the folk tales of "Belu Mau, Sabu Mau, and Ti'i Mau". The method used in this research is descriptive qualitative. Moreover, this study employed transcripts of stories from informants residing in Bello Village, Kupang City as sources of data. Interviews and observations were also conducted to collect data. The data were analyzed using the theory of sociology of literature from the perspective of Goldmann's genetic structuralism. Having analyzed, we can identify the local wisdom values encompassed in the folk tales of "Belu Mau, Sabu Mau, and Ti'i Mau", they are (1) Brotherhood value, this value is upheld by the three ethnic groups where they place brotherhood as the most essential bond, despite differences in religion, ethnicity, and geographical location; (2) Harmony value, it is a value based on mutual respect that has been maintained from generations; (3) Historical Value, it is the history of the three ethnic groups' journeys which became a milestone in unifying their relationship; (4) Religiosity value, it means brotherhood bonds which agreed upon in a traditional custom always deal with the religiosity understanding of other supreme being power; (5) Juridical value, the eternity of brotherhood bonds lies in their descendants who are bound by customary oaths and agreements.
\end{abstract}

Keywords: Belu Mau; Sabu Mau; Ti’i Mau; local wisdom

Abstrak
Secara geografis, Belu, Sabu, dan Rote (Ti'i) merupakan tiga kabupaten yang berada di tiga pulau
yang berjauhan di Provinsi Nusa Tenggara Timur. Dari tiga pulau, tiga kabupaten, dan tiga suku
tersebut, terdapat cerita rakyat yang menjadi legenda dan jarang diketahui oleh masyarakat
bahkan diteliti. Tujuan penelitian ini untuk mengungkap nilai-nilai kearifan lokal yang terkand-
ung dalam cerita rakyat "Belu Mau, Sabu Mau, dan Ti'i Mau". Metode yang digunakan dalam
penelitian ini adalah metode deskriptif kualitatif. Sumber data dalam penelitian ini adalah tran-
skrip cerita dari informan di Kelurahan Bello, Kota Kupang. Teknik pengumpulan data pada
penelitian ini adalah wawancara dan observasi. Data dianalisis dengan menggunakan teori sosi-
ologi sastra dalam perspektif strukturalisme genetik Goldmann. Dari hasil analisis ditemukan 
nilai-nilai kearifan lokal yang terkandung dalam cerita rakyat “Belu Mau, Sabu Mau, dan Ti'i Mau", yaitu (1) nilai persaudaraan, merupakan nilai yang dijunjung tinggi oleh ketiga suku tersebut dan menempatkan persaudaraan jauh lebih penting dari perbedaan agama, suku, dan pulau tempat mereka berdomisili; (2) nilai kerukunan, nilai yang dilandasi oleh rasa saling hormatmenghormati yang dipertahankan secara turun-temurun; (3) nilai historis, merupakan sejarah perjalanan tiga suku yang menjadi tonggak dalam mempersatukan hubungan mereka; (4) nilai religiositas, ikatan persaudaraan yang disepakati dalam adat selalu berurusan dengan pemahaman religiositas dari kekuatan lain; (5) nilai yuridis, kelanggengan persaudaraan terletak pada keturunan yang diikat oleh perjanjian dan sumpah adat.

Kata-kata kunci: Belu Mau; Sabu Mau; Ti’i Mau; kearifan lokal

\section{Pendahuluan}

Negara Indonesia merupakan negara yang terdiri atas beragam suku, beragam budaya, dan beragam bahasa. Keragaman budaya tersebut telah ada sejak lampau oleh pengaruh-pengaruh kebudayaan lain dan sejarah kebudayaan yang beraneka ragam selama berabad-abad telah dialami oleh masyarakat di Indonesia (Sunarti, 2015: 23).

Kebudayaan dalam masyarakat Indonesia, hidup dan berkembang seiring waktu yang berjalan. Sastra lisan merupakan bagian dari tradisi lisan atau istilah lain disebut folklor. Kata folklor merupakan pengindonesiaan kata bahasa Inggris folklore. Menurut (Browne and Dundes, 1967: 317), folk adalah sekelompok orang yang memiliki ciri-ciri pengenal fisik, sosial, dan kebudayaan, sehingga dapat dibedakan dari kelompok-kelompok lainnya. Selain itu, lore dipahami sebagai tradisi folk, yaitu sebagian kebudayaannya yang diwariskan turun-temurun secara lisan atau melalui suatu contoh yang disertai dengan gerak isyarat atau alat pengingat (mnemonic device).

Dalam setiap budaya kelisanan yang kental di Indonesia, di wilayah Timur Indonesia juga berperan sebagai penyumbang terbanyak sastra lisan, seperti cerita rakyat. Cerita rakyat dipahami memiliki nilai-nilai kearifan lokal yang dipandang dan dipercayai baik dalam memberikan kedamaian, ketenteraman, dan kebahagiaan hidup pada sesama manusia dalam bermasyarakat. Nilai- nilai yang dipandang baik tersebut tercermin ke dalam nilai-nilai kekerabatan, kerukunan, historis, religiusitas, maupun yuridis (Fatimah \& Sulistyo, 2013: 31).

Cerita rakyat termasuk ke dalam sastra lisan, di dalam cerita rakyat tersimpan kebudayaan yang luhur yang mengandung nilainilai kearifan yang luhur. Cerita rakyat merupakan salah satu bagian dari sastra lisan, folklor merupakan kumpulan prosa rakyat yang disebarluaskan dengan cara turuntemurun baik bentuknya berupa lisan ataupun dengan pelengkap gerak seperti alat bantu pengingat (Danandjaja, 2015: 45)

Sastra lisan di Pulau Timor, Nusa Tenggara Timur, merupakan bagian dari tradisi lisan yang hidup dan tetap eksis sampai saat ini. Salah satu jenis dari tradisi lisan yang sudah mulai terancam punah adalah cerita rakyat. Menurut (Unsriana, 2013: 310), cerita rakyat sebagai bagian dari folklor dapat dikatakan menyimpan sejumlah informasi sistem budaya seperti filosofi, nilai, norma, perilaku masyarakat. Dalam cerita rakyat, juga tersirat kearifan lokal yang terkandung di balik isi cerita tersebut. Kearifan lokal yang ada dalam cerita rakyat menyangkut moral maupun etika yang ditunjukkan pada dialog tokohnya. Moral dan etika tersebut merupakan bagian dari budi pekerti.

Bahasa terbesar di Pulau Timor adalah Dawan. Masyarakat Dawan memiliki kekayaan berbagai jenis sastra lisan. Sastra 
lisan yang pada umumnya masih ada dan digunakan dalam adat istiadat masyarakat Dawan, yaitu (1) bonet, sejenis puisi lisan yang dilantunkan pada saat tarian bonet, (2) heta, sastra lisan ini termasuk puisi lisan yang dilantunkan pada saat suasana santai, heta terdiri atas teka-teki dan peribahasa, (3) tonis, sastra lisan tonis berbentuk prosa yang dilantunkan pada saat adat berlangsung, tonis bisa menceritakan tentang sejarah dan masalahmasalah sosial yang ada di masyarakat, (4) $n u^{\prime} u$, sejenis sastra lisan prosa atau cerita rakyat yang biasa diceritakan di kehidupan masyarakat sehari-hari, (5) natoni, sejenis tuturan adat yang dilantunkan saat acara syukuran panen, kelahiran, menyambut tamu, dsb. yang melantunkan syair natoni disebut atoni dan yang menyambut tuturan natoni sebagai penegas adalah atutas (Iswanto, 2020: 87).

Dari uraian tersebut, cerita rakyat yang disebut $n u^{\prime} u$ oleh masyarakat Dawan tersebut adalah satu cerita yang sejak dulu sudah menjadi sejarah yang konon sudah didengar dan diceritakan oleh tetua adat di Pulau Timor, yaitu cerita ikatan tiga saudara, yaitu Sabu Mau, Ti'i Mau, dan Belu Mau. Saat ini, cerita itu sudah menjadi cerita yang langka diketahui oleh masyarakat. Di samping itu, kondisi pencerita yang sudah sangat sulit ditemukan dan usia pencerita sudah cukup tua, sehingga cerita ini bisa dikatakan di ambang kepunahan.

Penelitian tentang sastra lisan di Nusa Tenggara Timur sudah banyak dilakukan, di antaranya adalah (Liubana and Ibrahim Nenohai, 2020) yang meneliti tentang gaya bahasa figuratif dalam tuturan adat tonis dan temuan dari penelitian tersebut ditemukan banyak penggunaan gaya bahasa simile dan personifikasi yang terkandung dalam tuturan tonis. Kedua, (Santosa, 2016: 67) yang mengungkapkan dan mendeskripsikan kearifan budaya dan fungsi kemasyarakatan dalam sastra lisan Kafoa di Pulau Alor, Nusa Teng- gara Timur. Ketiga, (Thene, 2016:79) yang meneliti tentang mitigasi bencana gempa bumi berbasis kearifan lokal masyarakat Rote (Ti'i) di Provinsi Nusa Tenggara Timur mengungkapkan bahwa masyarakat Rote berkeyakinan bahwa bencana berkaitan dengan mitos dan kepercayaan terhadap makrokosmos dan mikrokosmos serta memberikan perasaan senasib, persatuan, dan kebahagiaan pascabencana.

Dari ketiga penelitian tersebut, yang menjadi dengan penelitian yang dilakukan peneliti ini adalah fokus. Penelitian ini berfokus pada nilai-nilai kearifan lokal dalam cerita rakyat sedangkan penelitian sebelumnya meneliti tentang nilai budaya, gaya bahasa, dan mitos. Atas dasar perbedaan penelitian dan latar belakang tersebut masalah yang ingin diungkap dalam tulisan ini adalah bagaimana nilai-nilai kearifan lokal yang terkandung dalam cerita rakyat Belu Mau, Ti'i Mau, dan Sabu Maujika dilihat dari telaah sosiologi sastra.

\section{Metode}

Penelitian ini termasuk jenis penelitian kualitatif, sesuai dengan kajian yang diuraikan bersifat deskriptif, yaitu data tulis atau data lisan dari orang atau perilaku yang diamati, khususnya terhadap cerita rakyat Belu Mau, Sabu Mau, dan Ti'i Mau. Sumber data penelitian ini berasal dari informan yang biasa bercerita dan menuturkan syair-syair dalam berbagai upacara adat. Informan yang dimaksud, yaitu tetua adat yang dalam struktur kemasyarakatan sebagai orang yang dipercayakan untuk menuturkan lisan cerita rakyat tersebut. Penentuan informan berdasarkan beberapa kriteria yang berhubungan dengan nama, usia, agama, pekerjaan, tingkat pendidikan, bahasa sehari-hari yang digunakan, dan kedudukannya dalam masyarakat.

Pengumpulan data mengarah pada metode yang diungkapkan oleh (Sudikan, 2015: 
25) menyatakan bahwa pengumpulan data sastra lisan menggunakan observasi, perekaman, wawancara, dan pencatatan. Sejalan dengan pengumpulan data itu, (Taum, 2011: 32) menyatakan bahwa pengamatan adalah proses melihat dan mengamati suatu kejadian (tari, permainan, tingkah laku, nyanyian, tuturan, dan lain-lain) dari gejala luarnya sampai ke dalamnya dan menggambarkan sebuah objek atau mendeskripsikan secara tepat hasil pengamatannya. Sejalan dengan pendapat tersebut, penelitian ini dilakukan dengan melakukan perekaman dan wawancara langsung kepada narasumber.

Jenis data yang digunakan dalam penelitian ini adalah data emik dan epik. Data emik merupakan data utama. Data emik dalam penelitian ini berasal dari narasumber, yaitu tuturan cerita atau $n u^{\prime} u$ pada masyarakat Dawan. Data etik dalam penelitian ini merupakan kisah atau pandangan pengalaman, wawasan/pengetahuan dari peneliti mengenai sosial budaya dalam kehidupan masyarakat Dawan. Teknik analisis data pada penelitian ini secara metodologis dilakukan dengan model analisis kualitatif Milles dan Huberman yang meliputi beberapa tahap, yaitu mengumpulkan data, mereduksi data, menyajikan data, transkripsi data lisan di dalam perekaman ke dalam bentuk tulisan, menerjemahkan hasil transkripsi dalam bahasa daerah ke dalam bahasa Indonesia, dan menarik kesimpulan (Milles, Huberman, and Saldana, 2014: 485). Sehubungan dengan hal tersebut, peneliti menerjemahkan cerita rakyat dengan terjemahan bebas. Selanjutnya, cerita rakyat Sabu Mau, Ti'i Mau, dan Belu Mau dianalisis dengan cara menginterpretasi dan mendeskripsikan makna dan nilai-nilai kearifan lokal yang terkandung di dalam cerita rakyat tersebut dengan pembacaan heuristik dan pembacaan hermeneutik. Selanjutnya, data dianalisis dengan menggunakan teori sosi- ologi sastra dengan pendekatan strukturalisme-genetik Goldmann.

Menurut Goldmann, strukturalismegenetik adalah analisis yang menyatukan aspek struktur dengan materialisme historis yang dialektik, sehingga karya sastra pun harus dipahami sebagai totalitas yang bermakna. Karya sastra memiliki kepaduan total dan unsur-unsur yang membentuk karya sastra mengandung arti. Arti karya sastra dapat dipahami dalam konteks sosial masyarakat yang melatarbelakanginya. Di sinilah strukturalisme genetik berkaitan dengan sosiologi karena pemaknaan struktur karya sastra ditempatkan dalam struktur masyarakat (Damono, 1979: 34)

\section{Hasil dan Pembahasan \\ 3.1 Sinopsis Cerita}

Riwayat Sabu Mau,Ti'i Mau dan Belu Mau. Belu Mau memperanak Mau Behi, Kupa Mau, Ti Mau, dan Huba Mau. Huba Mau ke Sumba. Ti Mau ke Rote. Kupa Mau ke Timor Barat selain Belu. Behi Mau tinggal tetap di Belu. Dalam perjalanan ketika mereka bertemu kembali setelah Pulau Sabu dilanda Tsunami. Dalam pertemuan kembali itu, mereka mencari tempat di mana saja agar mereka bisa bertemu. Diperkirakan mereka bertemu di Belu. Dalam pertemuan ini, seluruh tidak disebut orang-per-orang, tetapi semua disebut Hawu Mau. Hawu Miha ada tiga kali tujuh generasi yang tidak bisa disebut lagi karena generasi itu dianggap telah berlalu dengan Tsunami. India disebut Rai ahu nga temuni 'ari-ari dan segala hal kehidupan'.

Dalam perjalanan yang begitu jauh, setelah singgah ke sana ke mari, mereka singgah di Belu. Sesampai di Belu mereka membuat sumpah adat, bahwa harus menjaga tali persaudaraan karena semua ber-asal dari rai ahu nga temuni. Maka berangkatlah sebagian yang ke sabu, sebagian ke Rote. Sedangkan di Belu adalah yang kakak. Hawu Miha 
menetap di Sabu. Behi Miha saudaranya Kupa Mau. Thie Mau. Tie bisa diartikan sebagai sekat atau palang pematang. Kata $\mathrm{Ti}$ Mau dari kata ketinga atau doketi atau keras kepala. Penamaan berdasarkan tanda-tanda. Berapapun saudara kita, hanya satu yang paham tentang pesan dan tradisi orang tua. Antara Rote dan Sabu bisa berkelahi tanpa mendapatkan karma. Antara belu dan sabu selalu segan. Behi Miha (Belu): sikap memiringkan kepala, suatu cara merendahkan diri dan pola hidup yang bersahaja. Orang Belu, orang yang sedikit tahu adat. Ketika Sabu tenggelam, orang yang selamat, merasa tidak nyaman, maka mereka mesti mencari tempat perlindungan. Mereka kemudian sampai di Hura (kemungkinan India: Sura). Hu artinya ujung. $R a$ artinya darah. Hura artinya awal kehidupan. Hura berhubungan dengan puncak pertalian darah. Mereka harus kembali hidup setelah merasa telah mati dengan tenggelamnya Sabu. $R a$ berarti lambang kehidupan. Hau ra artinya darah keluar dari dalam tubuh.

Tokoh $R a$ generasi awal. Ra Rai, Pai $R a$, Maja Pai. Jawa: diparalelkan dengan kisah Yakub yang tidak punya bagian karena menipu ayahnya. Jawa dianggap luar Indonesia. Sabu yang tenggelam, dikatakan bahwa inisiatif dari Tuhan Deo Muri Mara. Artinya ada dari yang tiada. Ada dengan sendirinya. Rai heo'da. Sabu dianggap muncul dari lapisan kesembilan atau dari yang tertinggi. Lapisan kesembilan dianggap sebagai lapisan yang paling awal. Hawu Miha dan Behi Miha bersaudara. Behi Miha memperanakkan Kupa mau, Ti Mau, Belu Mau. Kisah pembentukan Pulau Sabu, prosesnya berawal dari $R a$ Rai (tidak bisa disebutkan). $R a$ dianggap sebagai pangkal segala sesuatu. Tali pusat Rai dianggap sebagai pangkal pembentukan pulau-pulau. Untuk itu, ketika Sabu tenggelam, Ludji adalah panglima perang, mau kia. Ludji Liru, panglima surgawi, bukan dari dunia yang sama dengan kita. Ketiga bersaudara ini bersumpah. Isi sumpah sebagai berikut:

turuna ngati he dau we di ta ae (kita berasal dari satu orang)

talowe lemadi bole pehala (biarkan telah

berkembang biak, tidak boleh berkelahi)

d'ai lohe la ana la app (sampai ke anak cucu)

do ju ta ae talowe mu (Walaupun kamu sudah bertambah banyak)

Ki pehala ta made ata, pakku ngaru, dai d'o la hobo kehaba do huli lajo la barri (Jika berbuat salah, akan mati muda, tidak akan beranak cucu dan tersesat (nasib tidak beruntung dan terkutuk).

Orang Sabu dan Belu pantang berkelahi. Jika orang sabu ingin tinggal di Belu, jangan pernah meminta bayaran. Begitu pun sebaliknya. Jadi, sampai sekarang masih pegang teguh tiga prinsip: (1) bole pehala pe alla (jangan berkelahi), (2) ie do ta pe uri pe loko (jangan adu ilmu gaib), (3) ki huli katu rai ha bole pema'i keb'ue (jika saling berkunjung jangan pernah minta bayaran (termasuk nikah tidak dipungut belis). Jika terjadi pelanggaran maka terjadi tido wila (mati muda), weo ngede (tidak mempunyai keturunan), atau mendapat petaka lain.

$\begin{array}{ll}\text { Narasumber } & : \text { Thomas Koroh } \\ \text { Usia } & : 53 \text { tahun }\end{array}$

\subsection{Nilai-Nilai Kearifan Lokal}

\subsubsection{Nilai Persaudaraan}

Ikatan komunal dalam perbedaan hanya dilandasi oleh kesadaraan akan persaudaraan. Karena itu kesetaraan dalam hak dan kewajiban hanya merupakan konsekuensi sosiologis. Persaudaraan dipahami dalam konteks geneologis dan sosiologis. Dalam konteks geneologis, ketiga suku ini menyadari bahwa mereka berasal dari satu nenek moyang, masih ada pertalian darah. Sedangkan dalam konteks sosiologis, persaudaraan mereka harus memperlihatkan pertemanan yang akomodatif dalam konteks sosial. 
Kekuatan kebersamaan dalam perbedaan (suku, agama, bahasa, dan tempat tinggal) hanya diikat oleh kesadaran persaudaraan. Oleh karena itu, kekerabatan harus dipahami dan diterima sebagai persaudaraan dari ikatan genelogis dan historis. Nilai persaudaraan dapat disimak pada kutipan cerita Perjalanan Belu Mau sebagai berikut:

Tiga saudara berjalan merantau dari tanah jauh (India) sampai di Belu ketiganya berunding untuk berpisah. Saudara yang satu ingin melanjutkan perjalanan ke Sabu, saudara yang satu melanjutkan perjalanan ke Rote, dan saudara yang satu memilih menetap di Belu. Namun, sebelum ketiganya berpisah, mereka mengucapkan janji untuk mempersatukan mereka. (Sumber cerita Belu Mau, Sabu Mau, dan Ti'i Mau)

Kutipan di atas menekankan, nilai kekerabatan yang dilandasi persaudaraan tanpa tendensi tertentu sangat penting untuk membangun keadaban dalam perbedaan distribusi biografis. Keadaan ini sesungguhnya terekspresi dalam hubungan antara ketiga suku ini. Perpisahan ketiga saudara ini bukan berdasarkan konflik atau revolusi, misalnya karena masalah tanah, atau masalah kekuasaan sebagai tipikal sejarah tradisional. Akan tetapi, perpisahan hanyalah berusaha mencari nafkah hidup. Karena itu, persaudaraan melewati distribusi geografis (tempat tinggal). Seorang informan menggarisbawahi hal tersebut ketika mengatakan:

Sampai hari, bahkan sampai kapan, selama kami memegang sejarah ini dan janji ini, kami tetap saling menghargai. Kami bersaudara. Meski tempat dan suku kami sekarang ini berbeda, tetapi kami telah diajarkan oleh nenek moyang untuk rukun selamanya. Jauhkan dari perbuatan yang saling merugikan. Banyak kisah yang terjadi akibat pelanggaran terhadap sumpah ini. Misalnya, di suatu waktu. Ada orang Belu yang menghamili gadis dari Rote, kemudian, ia tidak bertanggung jawab. Apa kebetulan atau tidak, lelaki itu kemudian ditabrak mobil dan mati di tempat. (Sumber cerita Belu Mau, Sabu Mau, dan Ti'i Mau)

Tiga hal penting yang menjadi rujukan kebijaksaan lokal (local wisdom). Pertama, Aliansi Belu Mau, Sabu Mau dan Tii merupakan aliansi moral. Dengan kata lain, aliansi terjadi bukan karena sejarah peperangan atau permusuhan sebelumnya, melainkan aliansi yang didasari oleh kolegialitas (persaudaraan). Karena itu, di manapun mereka berada, janji atau sumpah tersebut menjadi pedoman dalam pergaulan antara mereka. Kedua, perjanjian itu tidak mempunyai orientasi ekonomis dan politis, misalnya untuk perluasan kekuasaan sebagaimana terjadi pada suku lain pada zaman penjajahan. Aliansi ini murni berdasarkan kesadaran persaudaraan. Kutipan sumpah di bawah ini mempertegas hubungan persaudaraan tiga etnik tersebut.

turuna ngati he dau we di ta ae 'kita berasal dari satu orang'

talowe lemadi bole pehala 'biarkan telah berkembang biak, tidak boleh berkelahi'

d'ai lohe la ana la app 'sampai ke anak $\mathrm{cucu}^{\prime}$

do ju ta ae talowe mu 'Walaupun kamu sudah bertambah banyak'

Ki pehala ta made ata, pakku ngaru, dai d'o la hobo kehaba do huli lajo la barri 'Jika berbuat salah, akan mati muda, tidak akan beranak cucu dan nasib tidak beruntung'

Oleh karena itu, sampai saat ini, aliansi persaudaraan ini tetap langgeng. Suatu hal yang sangat dahsyat bagaimana perubahan sosial dewasa ini terus mengepung kehidupan dan mengikis nilai-nilai tradisonal yang pada akhirnya dapat kehilangan identitas kebangsaan. Lagi pula, sistem pewarisan cerita ini demikian baik sehingga dapat diketahui dan diikuti oleh generasi muda. Informan mengatakan:

"Biasanya kami diceritakan baik dalam ritual maupun dalam situasi biasa. Kebiasaan 
itu menceritakan itu dilakukan tidak hanya di Sabu atau di Rote, tetapi juga di tempat mana saja kami berada. Cerita itu, terus kami ceritakan kepada anak-anak kami, biar mereka tahu juga hubungan tiga suku supaya mereka tidak melakukan kesalahan yang sudah diucapkan dalam sumpah para leluhur". Kami harus saling hormat dan menghargai. Kalu orang Belu ke Sabu atau ke Rote, maka dia harus dibantu dan tidak boleh minta imbalan apapun. Kadang, cerita pada waktu upacara adat, kawin, kenduri, atau acara lain."(Sumber cerita Belu Mau, Sabu Mau, dan Ti'i Mau)

Pewarisan kisah dari generasi ke generasi sebagai kegiatan mental yang secara sistemik mengingatkan orang Belu, orang Sabu, dan orang Rote menyadari bahwa mereka hanyalah berpisah tempat tinggal. Akan tetapi, secara genealogis dan sosio-logis mereka pada dasarnya sedarah dan seketurunan. Oleh karena itu, di mana pun mereka berada akan ada pengakuan tentang persaudaraan. Bagi mereka, upacara atau ritual adat dipandang sebagai institusi untuk menyampaikan warta persaudaraan antara Belu, Sabu, dan Rote. Konteks upacara memberikan nilai mistis yang kalau tidak diikuti akan mendapat bencana atau petaka. Kisah itu menjadi kisah suci yang mengharuskan pendengar mengetahui seluk-beluk kisah itu, tetapi juga harus dilaksanakan apa yang menjadi pesan utama cerita tersebut. Leluhur selalu diwanti-wanti sebagai penitis kisah itu. Cara berkisah demikian, sosiologis dapat mempersatukan ketiga suku melalui kesadaraan dan kemudian menjadi pedoman dalam pertemanan atau pergaulan sehari-hari.

Dalam kehidupan sehari-hari, nilai persaudaraan ketiga etnik ini ditunjukkan misalnya bagaimana suku-suku itu diterima dan diposisikan secara hormat. Setiap orang Belu yang ke Sabu atau ingin menetap di Sabu harus diterima sebagai saudaranya. Jika dia menginginkan tanah diberikan sepantasnya tanpa dibeli, jika ia ingin menikah dengan orang Sabu, maka ia tidak dipungut belis/mahar. Demikian pun sebaliknya, jika orang Sabu atau Rote ke Belu akan diperlakukan serupa.

\subsubsection{Nilai Kerukunan}

Kerukunan merupakan harapan bagi semua masyarakat, terutama masyarakat multi etnik di manapun. Dalam banyak kasus di Indonesia, keragaman budaya selalu mengundang konflik. Dengan kata lain, pluralitas selalu berpotensi polaritas di kalangan masyarakat. Sejarah mencatat beberapa kasus konflik yang berkedok SARA dan menyebabkan horor sosial se-perti konflik Ambon, konflik Poso, konflik Ketapang, konflik Kupang, konflik Sampit dan konflik-konflik di daerah lainnya di Indonesia. Konflik ini seakan meminta Indonesia didefinisikan kembali sebagai negara bangsa. Namun, pada spektrum yang lain, keragaman justru menjadi kekuatan dan merekatan perbedaan.

Cerita rakyat Belu Mau (Belu), Ti'i Mau (Rote), dan Sabu Mau mewariskan bagaimana perbedaan itu menjadi kekuatan kerukunan. Kerukunan merupakan akibat wajar dari kesadaran persau-daraan di antara ketiga suku tersebut. Cerita Rakyat Belu Mau, Sabu, Ti'i Mau secara gamblang pentingnya persaudaraan mengatasi perbedaan. Keadaan demikian dapat disimak pada potongan kisah sebagai berikut:

Mereka sebenarnya tiga bersaudara. Mereka melakukan perjalanan dari India. Sesampai di Belu tiga bersaudara ini bermusyawarah. Ada yang ingin menetap di Belu, ada pula yang melanjutkan perjalanan ke Sabu dan Rote. Entah siapa yang kakak, siapa yang adik. Tidak diketahui pasti. Mungkin yang di Belu itu. Namun, sebelum ketiganya berpisah, mereka melalukan perjanjian agar mereka di mana pun berada selalu saling mengungat sebagai saudara. (Sumber cerita Belu Mau, Sabu Mau, dan Ti'i Mau) 
Persaudaraan hanya menjadi langgeng apabila ditata dalam pranata sosial bersama yang memfasilitasi hidup bersama. Karena itu, di mana pun suku itu bertemu harus dipandang sebagai persaudaraan. Dengan demikian, kerukunan antara mereka bukan diciptakan melainkan sebagai konskuensi dari kesadaran persaudaraan.

Hal penting dari kutipan di atas ialah bahwa mereka tidak menghiraukan di siapa kakak, siapa adik. Pernyataan itu, sesungguhnya agar tidak terjadi diskriminatis secara genealogis. Artinya, yang terpenting bagi mereka bukan masalah hie-rarki genelogis, melainkan kesataraan persaudaraan. Persaudaraan sejati justru terletak pada kesetaraan yang memperlihatkan gradasi secara sosiologis. Seorang informan mengatakan:

Terutama, Belu dan Sabu, sampai saat ini, kami di Kupang ini masih sangat teguh dengan perjanjian nenek moyang dulu. Intinya, kami tidak bolah saling menyakiti. Siapapun yang melakukan kesalahan harus sadar meminta maaf. Sebaliknya, orang yang diminta maaf harus ikhlas menerima maaf tanpa harus ada denda atau imbalan tertentu.(Sumber cerita Belu Mau, Sabu Mau dan Ti'i Mau)

Pernyataan di atas, setidaknya mengandung dua hal. Pertama, bahwa kesadaran akan persaudaraan menjadi tiang pokok dalam membangun kerukunan antar etnik yang beragam. Persaudaraan mengatasi perbedaan. Karena itu, kedua, pranata sosial seperti nilai-nilai dan norma yang disepakati oleh nenek moyang yang ditaati hingga saat ini justru menjadi fasilitas kultural yang sangat kuat mengikat kebersamaan etnik yang berbeda tersebut.

Nilai kerukunan dalam aliansi Belu Mau, Sabu Mau, dan Tii Mau sesungguhnya dibangun pula kesadaran akan penghargaan di antara mereka. Dalam kisah sebagai telah dikutip di atas tidak dijelaskan atau sengaja tidak dijelaskan siapa kakak dan siapa adik di antara mereka. Kisah itu sengaja ingin menyatakan bahwa mereka bersaudara tanpa hie-rarki yang saling mengobjeki satu dengan yang lainnya. Tak ada hirarki geneologis yang secara sosial harus taat pada hierarki tertentu dan konsekuensi lainnya. Persaudaraan sejati justru terbebas dari segala kepentingan termasuk memperjuangkan kepentingan bersama, tanpa memandang hirarki tertentu. Selain itu, ciri sosial pen-ting dalam pergaulan ketiga suku ialah kesediaan untuk memaafkan dan dimaafkan. Setiap individu ketiga suku yang melakukan kesalahan atau tidak sesuai dengan perjanjian maka harus dengan lapang dada untuk menyampaikan maaf. Sebaliknya, yang merasa dilukai dengan besar hati menerima permohonan dari orang yang melukai hatinya. Memaafkan dan dimaafkan menjadi faktor penting dalam membangun kerukunan dan perbedaan. Seorang informan mengatakan:

Memang sampai sekarang, kami anakanak ini tidak tahu siapa yang kakak dan siapa yang adik dari tiga bersaudara ini. Kami hanya tahu bahwa mereka tiga bersaudara yang datang dari jauh, dari India. Ada yang bilang dari Jawa. Tapi yang terpenting bagi kami bahwa kami bersaudara, dan sampai sekarang kami pegang teguh nasihat orang tua. Tidak boleh bermusuhan, tidak boleh menyakiti hati sesama saudara, perlakukan mereka sebagai saudara kandungmu.(Sumber cerita Belu Mau, Sabu Mau dan Ti'i Mau)

Keterangan di atas lebih dalam dapat dimaknai, warisan terpenting bagi keturunan tiga etnik tersebut bukanlah hartawi, melainkan persaudaraan dan bagaimana saling menghargai di antara mereka. Nasihat, "perlakukan mereka sebagai saudara kandung", bermakna bahwa apapun perbedaan bukanlah hal penting. Sebaliknya, perbedaan justru memperkuat hubungan persaudaraan. Artinya, jurang perbedaan etnik, tempat tinggal, perbedaan bahasa dan perbedaan 
agama dapat diratakan oleh kesadaran persaudaraan. Di atas kesadaran itu pula kerukunan bertumbuh dari generasi ke generasi.

\subsubsection{Nilai Historis}

Sejarah dalam konteks aliansi etnik Belu, Sabu dan Rote bukan sekadar album masa lalu yang berisikan romatisme perang, heroisme, adu kekuasaan, penakhlukan dan seterusnya, melainkan riwayat suci yang mendiktekan nilai, norma dan pandangan hidup yang menfasilitasi hubungan persaudaraan ketiga etnik tersebut. Karena itu, sejarah persaudaraan dalam bentuk dalam cerita rakyat terus hidup dan dihidupkan hingga saat ini. Karena itu, sejarah diterima dan dipahami sebagai sebuah nilai suatu etik yang mempedomani cara hidup bersama dalam perbedaan. Sejarah menyimpan banyak ajaran yang hendak diwariskan kepada generasi berikutnya.

Di Belu Selatan dekat Suai-Kemanasa (wilayah Timor Timor) terdapat sebuah gunung kecil yang di beri nama SabuMau. Kemungkinan besar, tempat yang sama inilah yang oleh orang Buna disebut Sabu-Lai. Di mana dianggap sebagai tempat bersumpah dan berpisahnya ketiga bersaudara yakni Belu-Mau,Sabu-Mau dan Ti-Mau. Sementara itu kita tahu bahwa gunung yang tertinggi di wilayah Amfoang adalah gunung yang bernama Timau. Kalau kita memperhatikan perjalanan rombongan Sonbai dari Belu Selatan menuju Mutis. (Sumber cerita Belu Mau, Sabu Mau dan Ti'i Mau)

Dalam konteks Belu Mau, Sabu Mau dan Tii Mau, sejarah adalah sebuah pesan. Pesan yang mengandung misi persekutuan persaudaraan. Sejarah menjadi indeks tekstual tentang hubungan ketiga suku bangsa ini. Bahkan ketiga etnik ini dibentuk oleh sejarah. Dalam kisah versi Orang Sabu misalnya:
Kemudian getek dikenal dengan nama orem bai dan loi dikenal dengan nama kora-kora. Di Timor, sebagian penduduk berpindah ke Rote dan Sabu, di mana sampai sekarang masih terdapat Negory atau Nusak di Rote yang selalu menghubungkan asal-usul mereka dengan Timor khususnya Belu. Nusak yang ada di Rote adalah Nusak Tii, yang termasuk juga dalam trilogi sakti Belu-Mau, SabuMau dan Ti-Mau. Selain itu juga ada Nusak Bilba, yang menurut arti etimologisnya berasal dari Belu-Ba yang berarti dari Belu pergi. (Sumber cerita Belu Mau, Sabu Mau dan Ti'i Mau)

Sejarah mempersatukan ketiga suku bangsa ini. Apapun perbedaan kisah sejarah itu, namun kisah-kisah tersebut berintikan perjalanan persaudaraan dengan sumpah yang menjadi wasiat antara ketiga etnik tersebut. Sejarah demikian penting dan terus menerus dihidupkan oleh orangporang dari ketiga etnik ini. Ini salah bentuk penyebaran nilai-nilai persaudaraan. Menceritakan kembali perjalanan mereka mengingatkan mereka akan penting sumpah sekaligus nilai-nilai sejarah yang mencerminkan perjalanan persaudaraan di antara tiga etnik tersebut.

Leluhur orang Rote bersama leluhur orang Belu datang dari Seram (Ternate). Mereka datang berkelompok, sebagiannya melalui Flores dan yang lainnya melalui Timor. (Sumber cerita Belu Mau, Sabu Mau dan Ti'i Mau)

Belu-Mau, Sabu-Mau, dan Ti-Mau, yang masih ditakuti hingga dewasa ini. Aliansi tiga etnik tersebut merupakan sumpah antara para leluhur dari ketiga suku bangsa, bahwa mereka serta seluruh keturunannya tidak boleh berkelahi satu sama lain. Pelanggarannya diancam dengan mati mendadak atau bencana lainnya. Hingga dewasa aliansi tersebut masih di- 
taati terutama antara Belu dan Sabu. Kuatnya aliansi sangat terkenal sampai ada orang Rote yang ingin menambah RoteMau, dan orang kisar menambah KisarMau, serta akhirnya orang semua menjelaskan tentang asal-usul pulau Se-mau dengan Pus-Mau.

Ada sebuah lagu Rote berna Feto Boine. Dalam lagu itu ada kalimat berbunyi: Falilosa papanaanuma Seram Belu mai. Artinya: kembali kepada cerita bapa katanya berasal dari Seram dan Belu. Mengenai pulau Ndao, hingga kini penulis tidak mempunyai data untuk penulisan seperti ini, meskipun kelihatan D.C. Saudale (semacam Pembantu Bupati) sudah memulai usaha pengumpulan data. (Sumber Cerita Asal-Usul Pulau Semau dengan Pus-Mau)

\subsubsection{Nilai Religiositas}

Religiositas selalu dihubungkan dengan kepercayaan akan suatu zat yang mengatasi hidup manusia dengan ciri utama tremendum dan misterium. Setiap komunitas mempunyai religiusitas yang diyakini sebagai kekuatan tertinggi tempat mengaduh dan mengeluh atas segala apa yang dilakukakannya. Hal unik lainnya, bahwa setiap masyarakat mempunyai metafora atau perlambangan tersendiri terhadap wujud tertinggi yang diyakininya itu.

Dalam masyarakat tradisonal, religiositas merupakan bagian dari ritual dan kebudayaan. Ritual sakral magik yang secara sosial memengaruhi cara hidup bersama di antara masyarakat pendukung tersebut. Nilai religiositas umum terejawantahkan dalam hubungan manusia dengan Tuhan. Pertama, perspektif terhadap wujud tertinggi, bagaimana sikap dan metanomia-metanomia yang berhubungan dengan wujud tertinggi. Kedua, nilai religius dapat dilihat dalam hubungan manusia dengan manusia. Perspektif antara sesama manusia. Siapa manu- sia per definisi komunitas setempat. Ketiga, hubungan manusia dengan alam semesta. Alam dipandang dan diperlakukan sebagai apa.

Dalam kisah Belu Mau, Sabu Mau, dan Ti'i Mau, gambaran religiositas dapat dilihat dari dua perspektif. Pertama, religiositas sebagai ritual sakral magis yang meligimitasi hukum adat yang mereka konstruksi. Dalam cerita versi sebagai berikut:

Ketika Sabu tenggelam, orang yang selamat, merasa tidak nyaman, maka mereka mesti mencari tempat perlindungan. Mereka kemudian sampai di Hura (kemungkinan India: Sura). Hu artinya ujung. $\mathrm{Ra}$ artinya darah. Hura artinya awal kehidupan. Hura berhubungan dengan puncak pertalian darah. Mereka harus kembali hidup setelah merasa telah mati dengan tenggelamnya Sabu. Ra berarti lambang kehidupan. Hau ra artinya darah keluar dari dalam tubuh. Tokoh Ra generasi awal. Ra Rai, Pai Ra, Maja Pai. Jawa: diparalelkan dengan kisah Yakub yang tidak punya bagian karena menipu ayahnya. Jawa dianggap luar Indonesia. Sabu yang tenggelam, dikatakan bahwa inisiatif dari Tuhan Allah Deo Muri Mara. Artinya ada dari yang tiada. Ada dengan sendirinya. Rai heo'da. Sabu dianggap muncul dari lapisan kesembilan atau dari yang tertinggi. Lapisan kesembilan dianggap sebagai lapisan yang paling awal. Hawu Miha dan Behi Miha bersaudara. Behi Miha memperanakan Kupa Mau, Ti Mau, Belu Mau. Kisah pembentukan pulau Sabu, prosesnya berawal dari $\mathrm{Ra}$ Rai (tidak bisa disebutkan). Ra dianggap sebagai pangkal segala sesuatu. Tali pusat Rai dianggap sebagai pangkal pembentukan pulau-pulau. Maka ketika Sabu tenggelam, Ludji adalah panglima perang, mau kia.(Sumber cerita Belu Mau, Sabu Mau dan Ti'i Mau)

Dalam kutipan itu dapat dipahami bahwa hidup mereka sangat tergantung pada wujud 
tertinggi. Apapun keadaan di dunia ini hanya menurut kehendak Wujud Tertinggi. Di samping itu, metafora wujud tertinggi sangat kontekstual dengan kehidupan mereka. Bagi mereka, wujud tertinggi dapat mendatangkan murka selama tidak sanggup membangun komunikasi yang harmonis dengan wujud tertinggi.

\subsubsection{Nilai Yuridis}

Ritual, nilai, norma dan aturan dilegitimasi secara juridis atau hukum yang berlaku di negara mereka. Dalam kisah Belu Mau, Sabu Mau, Ti'i Mau sangat jelas tergambar bahwa ada perjanjian di antara mereka untuk tidak saling menyakiti atau saling merugikan satu sama lainnya. Keutamaan mereka pada kesadaran akan pentingnya persaudaraan. Oleh karena itu, kesadaran akan sulit diwariskan tanpa dilakukan penguatan melalui nilai juridis atau keberterimaan sanksi atau hukuman yang disepakati bersama oleh individuindividu komunitas tersebut. Bahkan, kekuatan persaudaraan ketiga etnik sangat ditentukan oleh perjanjian adat yang mereka lakukan tersebut.

Kalau mereka dan keturunan mereka berkelahi atau saling berperangan, mereka masuk ke dalam tanah (mati mendadak) sebagai mana gumpalan darah itu dikuburkan. Dalam hal penerusan sumpah leluhur ini, orang Belu mengatakan bahwa peristiwa itu terjadi di Belu dan Belu-Mau yang menjadi kakak. Sebaliknya orang Sabu akan menceritakan bahwa sumpah itu terjadi di Sabu dan Sabu-Mau yang menjadi kakak.(Sumber cerita Belu Mau, Sabu Mau dan Ti'i Mau)

Kisah Belu Mau, Sabu Mau dan Ti'i Mau dalam versi orang Sabu sangat kental akan nilai religius yang terkandung di dalamnya. Hal tersebut dapat dilihat dari "Sumpah" dalam masyarakat Sabu. Sumpah merupakan hukum atau konvensi paling ampuh dalam mematuhi kesepakatan.
Karena itu, sumpah ketiga bersaudara itu harus dikisahkan secara turun temurun sehingga kekuatan yuridis sumpah itu tetap langgeng dari generasi ke generasi. Sumpah tidak hanya dirumuskan dalam kalimat serapah, pendek dan tegas, tetapi juga disiarkan melalui syair tertentu agar mudah dingat dan mudah dituturkan seperti pada kutipan berikut ini:

\section{"Te afi Liurai nok sombai \\ non in paha ma non in nifu}

Nsae nein noko un tenu ma baan teun

Belu-Mau, Sabu-Mau ma Ti-Mau,

Onunu,Maubeis, Oebkok hautiom,

Dirma ma lakekun...."

Terjemahannya:

Karena sewaktu liurai dan Sonbai menjalin (menyelidiki) kerajaan (tanah dan danaunya) ialah mereka yang keluar dari tiga pokok dan tiga akar yaitu Belu-Mau, Sabu-Mau, dan TiMaudara Oenunu, Maubesi, Wewiku, Hatimuk - Dirma, dan Lakekum.

Cara pewarisan seperti ini, dapat melanggengkan perjanjian. Setiap ritual penting, syair ini sering diperdengarkan agarmengingatkan pentingnya perjanjian persaudaraan itu, sekaligus mengingatkan generasi berikutnya akan adanya perjanjian para leluhur tentang persaudaraan tiga Belu, Sabu dan Rote.

Mereka kemudian dalam perjalanan yang begitu jauh, setelah singgah ke sana ke mari, mereka singgah di Belu. Di situ dibuat sumpah adat, bahwa harus menjaga tali persaudaraan karena semua berasal dari rai ahu nga temuni. Maka berangkatlah sebagian yang ke Sabu, sebagian ke Rote. Maka yang di Belu adalah yang kakak. Hawu Miha menetap di Sabu. Behi Miha saudaranya Kupa Mau. Tie Mau.(Sumber cerita Belu Mau, Sabu Mau dan Ti'i Mau)

Sampai saat ini, perjanjian adat tersebut masih dipegang kuat oleh masyarakat 
tiga etnis di tiga pulau tersebut. Kesepakatan yang telah menjadi suatu ikatan itu mengandung konsekuensi yang selama ini tetap mereka percayai dapat menjadi malapetaka apabila dilanggar.

\section{Simpulan}

Cerita rakyat sederhana apapun juga dapat diyakini mengandung nilai-nilai tertentu yang bermanfaat bagi masyarakat sang empunya cerita. Dalam sejarah rakyat Belu Mau, Sabu mau, Ti'i Mau, ditemukan nilai-nilai kearifan yang menjadi pedoman hidup ketiga etnik itu. Nilai kearifan lokal tersebut dapat disimpulkan sebagai berikut, (1) nilai persaudaraan, bagi orang Sabu, Belu Mau, dan Rote persaudaraan jauh lebih penting dari apapun, nilai persaudaraan dapat menghilangkan perbedaan agama, suku, dan pulau tempat mereka berdomisili; (2) nilai kerukunan, rasa rukun tercermin dalam kedamaian hidup rukun bersama dalam persaudaraan dan saling pengertian dari keragaman baik dari aspek bahasa, agama dan tempat tinggal. Kerukunan yang dibangun harus dilandasi oleh rasa persaudaraan sejati. Oleh karena itu, kelanggengan persaudaraan dapat terwujud apabila dibangun dalam nilai kerukunan yang dipertahankan secara turun-temurun; (3) nilai historis, sejarah persekutuan Belu Mau, Sabu Mau, dan Ti'i Mau adalah sejarah perjalanan suku bangsa yang berisikan nilai yang dapat mempersatukan mereka. Tanpa mengenal sejarah berarti pula tidak mengenal persekutuan tersebut. Karena itu, bagi tiga etnik ini sejarah menjadi bagian nilai penting guna mewariskan persekutuan harmonis antara tiga etnik tersebut; (4) nilai religiositas, ikatan persaudaraan yang disepakati dalam adat selalu berurusan dengan kekuatan lain. Dengan kata lain, kekuatan sebuah sumpah adat dilakukan di hadapan sesama manusia, leluhur dan Wujud Tertinggi. Karena itu, hubungan segitiga ini dapat menentukan ikatan per- saudaraan dan cara hidup mereka; (5) nilai yuridis, Kelanggengan persaudaraan terletak pada dua hal. Pertama, persaudaraan yang yang terjadi melalui kesadaran secara genealogis atau keturunan. Artinya, mereka menyadari ke belahan dunia mana pun mereka pergi akan tetap bersaudara. Kedua, ikatan persaudaraan bagaimana pun akrabnya akan langgeng dan kuat jika diikat oleh perjanjian dan sumpah adat. Nilai yuridis inilah yang menjadi inti dari persaudaraan tiga etnis, Belu Mau, Sabu Mau, dan Ti'i Mau di Provinsi Nusa Tenggara Timur.

\section{Daftar Pustaka}

Browne, R. B., \& Dundes, A. 1967. The Study of Folklore. Dalam The Journal of American Folklore.Volume 80, Nomor 317. https:/ / doi.org/10.2307/537878

Damono, Sapardi Djoko.1979. Sosiologi Sastra Sebuah Pengantar Ringkas. Jakarta: Departemen Pendidikan dan Kebudayaan.

Danandjaja, J. 2015. Pendekatan Folklor dalam Penelitian Bahan-bahan Tradisi Lisan. Yogyakarta: Yayasan Pustaka Obor.

Fatimah, F. N., \& Sulistyo, E. T.2013. Cerita Rakyat Dewi Sritanjung sebagai Upaya Mewujudkan pendidikan Karakter Berbasis Nilai Kearifan Lokal. Dalam Proceeding of 2nd International Conference of Arts Language And Culture.

Iswanto, I. 2020. Tradisi Lisan Natoni dalam Tuturan Ritual Sium Ana pada Masyarakat Boti di Nusa Tenggara Timur. dalam Walasuji: Jurnal Sejarah dan Budaya. Volume 11, Nomor 1, hlm. 87--96. https:/ / doi.org/10.36869/wjsb.v11i1.70

Liubana, M. M. J., \& Ibrahim Nenohai. 2020. Bahasa Figuratif dalam Tonis Masyarakat Dawan di Kabupaten Timor 
Tengah Selatan. Dalam Jurnal Onoma: Pendidikan, Bahasa, Dan Sastra.Volume 6, Nomor 2, hlm. 567--576. https://doi.org/10.30605/onoma.v6i2350

Milles, M. B., Huberman, M. A., \& Saldana, J. 2014. Qualitative Data Analysis A methods Sourcebook Edition 3. Dalam Jurnal Zeitschrift fur Personalforschung. Volume 28, Nomor 4, hlm.485-487. https:/ / doi.org/10.1177/2397002214028 00402

Santosa, P. 2016. Kearifan Budaya dan Fungsi Kemasyarakatan dalam Sastra Lisan Kafoa. Dalam Metasastra: Jurnal Penelitian Sastra. Volume 5, Nomor 1, hlm.67. https:// doi.org/10.26610/metasastra.20 12.v5i1.67-82

Sudikan, S. Y.2015. Pendekatan Interdisipliner, Multidisipliner, dan Transdisipliner dalam Studi Sastra. Dalam Jurnal Paramasastra. Volume 2,
Nomor $\quad 1, \quad$ hlm.25--36. https://doi.org/10.26740/parama.v2i1.1496

Sunarti, S. (2015). Mendengar Nenek Moyang Turun dari Langit: Motif Cerita AsalUsul Suku di Alor. Jakarta: LIPI Press.

Taum, Y. Y. 2011. Studi Sastra Lisan: Sejarah, Teori, Metode, dan Pendekatan, Disertai Dengan Contoh Penerapannya.Yogyakarta: Lamalera.

Thene, J.2016. Mitigasi Bencana Gempa Bumi Berbasis Kearifan Lokal Masyarakat Rote Kabupaten Rote Ndao Provinsi Nusa Tenggara Timur. Jurnal Teori Dan Praksis Pembelajaran IPS. https://doi.org/10.17977/um022v1i22016p102

Unsriana, L. 2013. Nilai Kearifan Lokal dalam Cerita Rakyat Jepang (Minwa). Dalam Jurnal Humaniora. Volume 4, Nomor 1, hlm.310--321.

https://doi.org/10.21512/humaniora.v4i1.3441 